\title{
Fingerroot (Boesenbergia pandurata) Extract Inhibits Proliferation and Migration of 4T1 Metastatic Breast Cancer Cells
}

\author{
Marsya Yonna Nurrachma ${ }^{1}$, Gergorius Gena Maran ${ }^{1}$, Nindya Budiana Putri ${ }^{1}$, Yuni Fajar Esti ${ }^{1}$, \\ Adam Hermawan ${ }^{1,2}$, Edy Meiyanto ${ }^{1,2}$, Riris Istighfari Jenie ${ }^{1,2^{*}}$ \\ ${ }^{1}$ Cancer Chemoprevention Research Center, Faculty of Pharmacy, Universitas Gadjah Mada, Yogyakarta, Indonesia \\ ${ }^{2}$ Department of Pharmaceutical Chemistry, Faculty of Pharmacy, Universitas Gadjah Mada, Yogyakarta, Indonesia
}

\begin{abstract}
Fingerroot (Boesenbergia pandurata) is an Indonesian herb, with anti-proliferation and anti-migratory effects against several cancer cells. This study aims to investigate the anticancer property of Fingerroot Extract (FE) in combination with doxorubicin (Dox) against $4 \mathrm{~T} 1$, a metastatic breast cancer cell lines. FE was prepared by $96 \%$ ethanol maceration and characterized by thin-layer chromatography analysis. FE was subjected to a cytotoxicity test with 3-(4,5-dimethylthiazol-2-yl)-2,5-diphenyl tetrazolium bromide (MTT) assay alone or in combination with $10 \mathrm{nM}$ Dox against 4T1 cells. Cytotoxic effect was then confirmed by measure reactive oxygen species (ROS) intracellular level using $2^{\prime}, 7^{\prime}$-dichloroflourescin diacetate (DCFDA)-staining flow cytometry-based assay. The anti-migratory effect was observed using scratch wound healing assay and gelatin zymography to investigate matrix metalloproteinase (MMP)-9 expression. FE showed a cytotoxic effect with an inhibitory concentration $50\left(\mathrm{IC}_{50}\right)$ value of $25.5 \pm 3.9 \mu \mathrm{g} / \mathrm{mL}$ and performed an improved effect in combination with $10 \mathrm{nM}$ Dox. A single treatment of FE decreased ROS intracellular level, while in combination with Dox, FE increased the ROS intracellular level. Further, at $42 \mathrm{~h}$ observation, FE and its combination with Dox inhibited the migration of 4T1 cells with $\%$ closure of 82.6 and 82.5 , respectively, correlates with a significant decrease of MMP-9 expression. Overall, FE performs a cytotoxic activity and anti-migration activity on 4T1 breast cancer cells.
\end{abstract}

Keywords: Boesenbergia pandurata, cytotoxic, ROS, anti-migration, 4T1

\section{INTRODUCTION}

Triple Negative Breast Cancer (TNBC) is one of the foremost troublesome sorts of cancer to cure since it incorporates a destitute guess (Blows, et al., 2010; Adrada, et al., 2014). Furthermore, most breast cancer patients who express TNBC phenotype are metastatic which result in difficult healing process and increase the risk of patients' death (Ma, et al., 2012). Metastasis defines as a dissemination process in which cancer cells migrate and grow on other organs, continuously proliferate resulting in a new tumour mass (Brooks, et al., 2010). On the other hand, doxorubicin which is often used in TNBC therapy often causes failure in therapy and triggers the process of migration through the formation of lamellipodia (Vinod, et al.,

Submitted: July 5, 2020

Revised: July 20, 2020

Accepted: July 20, 2020

*Corresponding author: riris_jenie@ugm.ac.id 
2013; Mehta, et al., 2013, Bandyopadhyay, et al., 2010, Amalina, et al., 2017). Nonetheless, the most widely used treatment for cancers nowadays is still chemotherapy though resistance and recurrence remain crucial problems (Wilson, et al., 2009). Therefore, it is necessary to explore alternative treatments that safer and more affordable, one of them through the exploration of natural materials.

Fingerroot (Boesenbergia pandurata) is an Indonesian original rhizome containing various flavonoid compounds such as panduratin $\mathrm{A}$, boesenbergin $\mathrm{A}$, boesenbergin $\mathrm{B}$, cardamonin, and dihydromethoxychalcone (Kirana, et al., 2007), has been observed its anticancer activity through apoptotic induction, cell cycle disruption, reactive oxygen species (ROS) induction, and antiangiogenesis (Nurrachma, et al., 2018). Panduratin A known to inhibit the growth of HepG2 cancer cells (Sohn, et al., 2005), MCF-7 breast cancer cells, and HT-29 human colon adenocarcinoma cells (Kirana, et al., 2007). Furthermore, Isa, et al. (2013) reported that boesenbergin A was able to induce apoptosis in A549 lung cancer cells through the formation of ROS. In addition, pinostrobin induced ROS generation in PC12 kidney cancer cells (Xian, et al., 2012). Likewise, panduratin $\mathrm{A}$ is also able to inhibit vascular endothelial growth factor (VEGF), a pro-angiogenesis factor (Lai, et al., 2012).

In this study, we used 4T1 cells as a TNBC model, characterized with lack of estrogen receptor, progesterone receptor and human epidermal receptor-2 (HER-2) expression (Bao, et al., 2011), and also high metastatic ability (Kaur, et al., 2012). Thus, this cell line is a suitable model for exploring an anti-breast-cancer agent with high metastatic properties. This study aims to explore the potency of Fingerroot Extract (FE) as a co-chemotherapeutic agent combined with doxorubicin to provide a synergistic effect in inhibiting the development of highly metastatic breast cancer. The anti-proliferation activity of FE and its combination with Dox was outlined using cytotoxic assay and focusing on the intracellular
ROS level. Furthermore, anti-migration and antiinvasion activity of FE was performed to exhibits its anti-metastatic potency. Thus, the results of this study are used as supporting data to develop FE as a cancer co-chemotherapy agent in highly metastatic breast cancer cells.

\section{MATERIALS AND METHODS}

\section{Extract Preparation and Thin Layer Chromatography}

Fingerroot was obtained from Bina Agro Mandiri Inc. (Bantul, Yogyakarta, Indonesia) and determined by Pharmaceutical Biology Department, Faculty of Pharmacy, Universitas Gadjah Mada, Yogyakarta, Indonesia. It was macerated, and remacerated with $96 \%$ ethanol (1:10) for 8 days. The filtrate was dried using a vacuum rotary evaporator at $40-50^{\circ} \mathrm{C}$, resulting in viscous extract.

FE was identified by thin-layer chromatography (TLC) using silica gel $60 \mathrm{~F}_{254}$ (Merck, Darmstadt, Germany) as stationary phase and n-hexane: ethyl acetate $(4: 1)$ as the mobile phase. A total of $5 \mathrm{mg}$ extract was dissolved in 0.5 $\mathrm{mL}$ ethanol (Merck). The chromatogram profile was observed under visible light, UV 254 and $266 \mathrm{~nm}$ (in-house specification). It was sprayed with citroboric reagents to identify the flavonoid contents, then compared with 100 -fold value of retardation factor (hRf) of standardized $\mathrm{FE}$ in Indonesian Herbal Pharmacopeia $1^{\text {st }}$ Edition (2008).

\section{Cell Culture}

The 4T1 breast cancer cells (ATCC ${ }^{\circledR}$ CRL2359) were obtained from Prof. Masashi Kawaichi, (Nara Institute of Science and Technology, Japan). The cells were cultured in Dulbecco's Modified Eagle's Medium supplemented with 10\% Fetal Bovine Serum (Sigma, St. Louis, USA), penicillinstreptomycin (10.000 Unit/mL penicillin, 10.000 $\mu \mathrm{g} / \mathrm{mL}$ streptomycin) (Gibco, New York, USA), and $0.5 \%$ fungizone (Gibco) under standard conditions $\left(37^{\circ} \mathrm{C}, 5 \% \mathrm{CO}_{2}\right)$. 


\section{Cytotoxic Assay}

Cytotoxic assay was carried out using 3-(4,5-dimethylthiazol-2-yl)-2,5-diphenyl tetrazolium bromide (MTT) assay adopted from Mosmann, 1983. Cells $\left(2.5 \times 10^{3}\right)$ were seeded into each well of a 96-well plate and incubated for 24 h. After incubation, the cells were treated with FE at single concentration of $2.5-50 \mu \mathrm{g} / \mathrm{mL}$ and in combination with $10 \mathrm{nM}$ Dox (Sigma). Media were discarded, and cells were washed with $100 \mu \mathrm{L} /$ well $1 \mathrm{X}$ phosphate-buffered saline (PBS). Then, MTT reagent (Sigma) was added, incubated in $37^{\circ} \mathrm{C}$ for $4 \mathrm{~h}$ then $10 \%$ sodium dodecyl sulphate (SDS) in $0.01 \mathrm{~N} \mathrm{HCl}$ was added, incubated overnight, and the absorbance was measured using a microplate reader (Bio-Rad) with $\lambda=595 \mathrm{~nm}$.

\section{2',7'-dichloroflourescin Diacetate (DCFDA) Staining}

The changes in the intracellular level of ROS were monitored using the fluorescent probe DCFDA, a specific probe for hydrogen peroxide. The $4 \mathrm{~T} 1$ cells $\left(5 \times 10^{4}\right)$ were seeded into each well of a 24-well plate and incubated overnight. After incubation, the cells were treated with $100 \mu \mathrm{L}$ of $\mathrm{FE}$ and Dox in the concentration of $10 \mu \mathrm{g} / \mathrm{mL}$ and $10 \mathrm{nM}$, respectively, for $24 \mathrm{~h}$. Media were discarded and cells were washed with $1 \mathrm{X}$ PBS. Cells were collected using trypsin-EDTA $0.25 \%$ (Gibco) and resuspended with $400 \mu \mathrm{L} 1 \mathrm{X}$ supplemented buffer in microtube and stained with $3.75 \mu \mathrm{L} 2 \mathrm{mM}$ DCFDA (30 min, $37^{\circ} \mathrm{C}, 5 \% \mathrm{CO}_{2}$ incubation). The DCF fluorescence of at least 20,000 cells was detected and analyzed using flow cytometry (BD Accuri C6 flow cytometer) with an excitation wavelength set at $488 \mathrm{~nm}$ and an emission wavelength set at 525 $\mathrm{nm}$.

\section{Scratch Wound Healing Assay}

Migration assay was carried out by scratch wound healing assay adapted from Liang, 2007. 4T1 Cells $\left(7.5 \times 10^{3}\right)$ were grown into each well of 24-well plate overnight and starved in a starvation medium for $24 \mathrm{~h}$. Each well was scratched vertically using a yellow pipette tip and treated with FE, Dox, and a combination of both agents. The closures of cell migration were documented at 0,24 , and 42 h using digital camera (Nikon Coolpix S800c). Quantification of the closures area was calculated using ImageJ software (National Institutes of Health, Maryland, USA).

\section{Gelatin Zymography of MMP-9 Expression}

MMP-9 expression was traced through the gelatin zymography-based assay. 4T1 Cells $\left(3 \times 10^{5}\right)$ were seeded into each well of 6-well plate then incubated for $24 \mathrm{~h}$. The cells were treated with FE, Dox, or a combination of both agents in serum-free medium. Cells were washed with cold PBS and added with cold lysis buffer. The solution was centrifugated at $400 \mathrm{~g}$ for $3 \mathrm{~min}$ at $4^{\circ} \mathrm{C}$. The protein calculation was conducted using Bradford assay method. The lysate was subjected for gel electrophoresis on $8 \%$ SDS-PAGE gel containing $0.1 \%$ gelatin under conditions of $120 \mathrm{~V}$ and $80 \mathrm{~mA}$ for $110 \mathrm{~min}$. The gel was denatured with a denaturing solution containing $2 \%$ Triton- $X$ in aquadest for 30 min and incubated with incubation buffer for 24 $\mathrm{h}$, and then stained with $0.5 \%$ Coomassie Brilliant Blue and incubated for $30 \mathrm{~min}$. After $30 \mathrm{~min}$, the gel was destained to form a transparent band with a dark blue background. The gel was scanned and documented. Band intensities were measured using ImageJ software (National Institutes of Health).

\section{Statistical Analysis}

Data presented as mean $\pm \mathrm{SE}$, except for MTT Cytotoxic Assay (mean \pm SD) followed by statistical analysis using One Way ANOVA. $P$-values $(* p<0.05, * * p<0.1)$ are included in each experiment figure.

\section{RESULTS}

\section{Characterization of Fingerroot Extract using} Thin Layer Chromatography

Fingerroot extraction yielded $16.87 \%$ $\mathrm{w} / \mathrm{w}$ brown viscous extract. The extract was 
characterized based on the chemical profile to identify the conformity between FE and the standard in literature.

We used TLC to figure the separation profile of its chemical content and compared with standardized FE based on Indonesian Herbal Pharmacopoeia $1^{\text {st }}$ Edition (2008). Under UV light $254 \mathrm{~nm}$ (Figure 1), we obtained yellow and blue spots at hRf of $9,17,28,35,63,75,83$, which similar to the standardized FE profile. The citroboric spraying of TLC plate under UV light $366 \mathrm{~nm}$ appeared 8 yellow spots on hRf of $9,25,34,55,63,68,75,83$, which predicted to be flavonoid (Figure 1.2; Wagner $\&$ Bladt, 1996). Furthermore, the spots at hRf of 64 have a similar position to pinostrobin (Figure 1.1) a marker compound in fingerroot (Health Ministry of Indonesia, 2008).

\section{Cytotoxic Activity of Fingerroot Extract- Against 4T1 Cells}

Anti-proliferation activity of FE was investigate using MTT cytotoxic assay towards 4T1 breast cancer cells. Our results showed that treatment of FE for $24 \mathrm{~h}$ exhibited $\mathrm{IC}_{50}$ of $25.5 \pm 3.9 \mu \mathrm{g} /$ $\mathrm{mL}$ in a dose-dependent manner (Figure 2) which categorized as high cytotoxic potency according to Prayong, et al. (2008). The combination of $10 \mu \mathrm{g} /$ $\mathrm{mLFE}$ and $10 \mathrm{nM}$ Dox showed to reduce the $\%$ cell viability up to $35 \%$ compared to a single treatment of these compound (Figure 3.2). Since ROS intracellular level contribute to the cytotoxic activity, we used DCFDA-staining flow cytometry-based assay to measure ROS level.

\section{Effect of Fingerroot Extract on Reactive Oxygen Species Level in 4T1 Cells}

To investigate whether FE treatment correlates with ROS level, we carried out DCFDA-staining flow cytometry-based assay to measure intracellular ROS level on 4T1 cells. Our results showed that $24 \mathrm{~h}$ FE treatment decreased intracellular ROS level, while in combination with Dox, FE increased the level of intracellular ROS level (Figure 4). Since low concentration of Dox

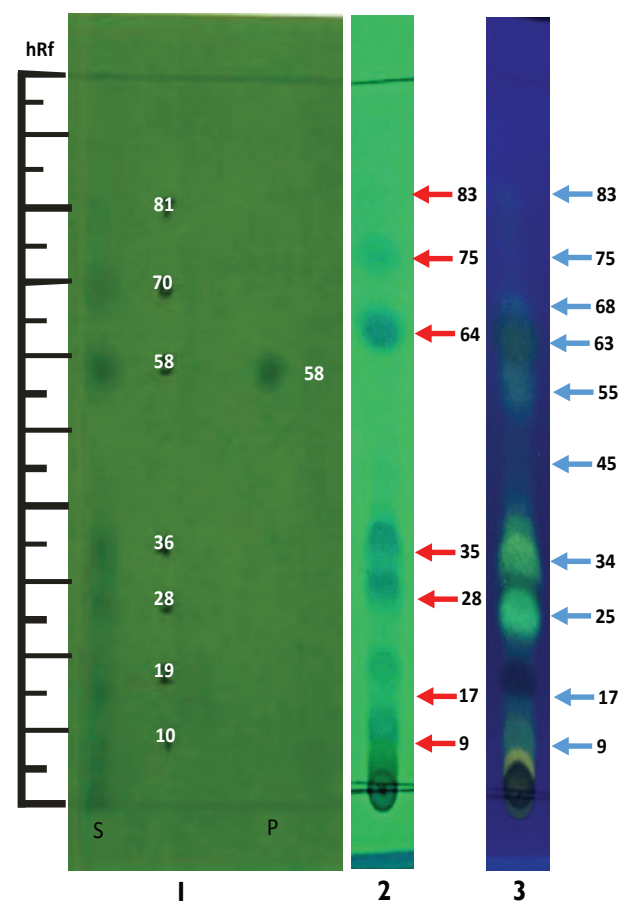

Figure 1. Characterization of FE with Thin Layer Chromatography. (1) TLC profile of standardized FE based on Indonesian Herbal Pharmacopoeia $1^{\text {st }}$ Edition (2008). S: standardized FE, P: pinostrobin. Stationary phase: silica gel $60 \mathrm{GF}_{254}$, mobile phase: $\mathrm{n}$-hexane: ethyl-acetate (4:1). The plate was observed under (2) $254 \mathrm{~nm}$ and (3) $366 \mathrm{~nm}$ UV light (after citroboric spray). Red arrows: spots which had similar hRf value with standardized FE. Blue arrows: compounds that are predicted to be flavonoids. 

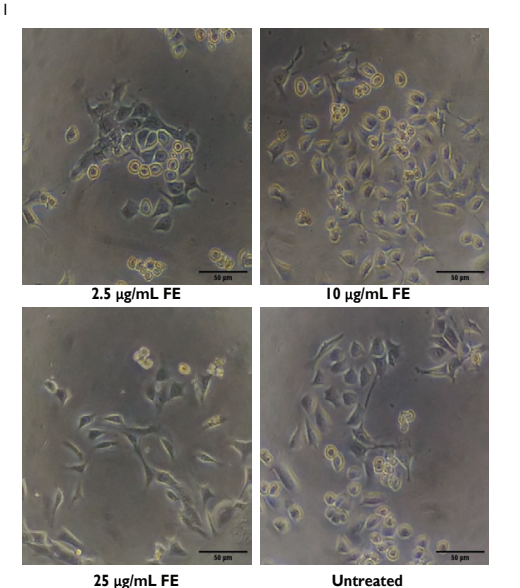

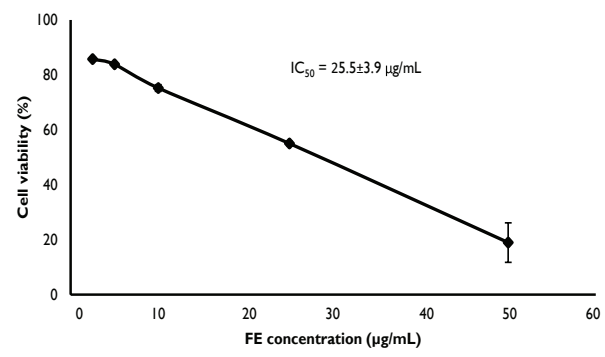

Figure 2. Effect of FE on the proliferation of 4T1 cells. (1) The morphology of 4T1 cell after treatment of FE. Morphological observations of cells were carried out with an inverted microscope with 100x magnification. (2) Cytotoxic profile of FE on 4T1 cells. The data was displayed as an average of mean \pm SD $(n=2)$.

was known to induce cell migration (Amalina, et al., 2017), we performed scratch wound healing assay to scrutinize the anti-migration activity of FE on 4T1 breast cancer cells.

\section{Combination of Fingerroot Extract and Doxorubicin in 4T1 Cells Migration}

We performed scratch wound healing assay to explore anti-metastatic potency of FE on 4T1 highly metastatic cell. Our result showed that FE and in combination with Dox were able to inhibit 4T1 cells migration (Figure 5.1). We obtained that FE and in combination with Dox (42 h) significantly inhibited cell migration compared to the untreated group with closure of $82.6 \%$ and $82.6 \%$, respectively (Figure 5.2). Whilst, single treatment of Dox induced cell migration with closure up to $95.7 \%$. Moreover, we then conducted gelatin zymography assay to examine FE ability to inhibit invasion of 4T1 cells through reducing MMP-9 expression.
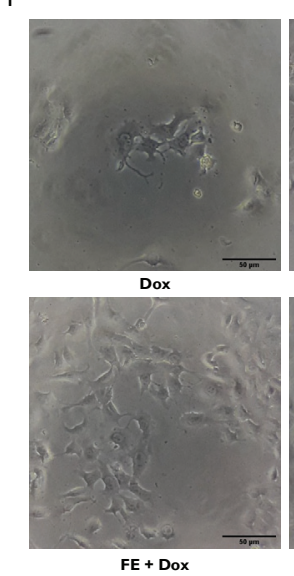
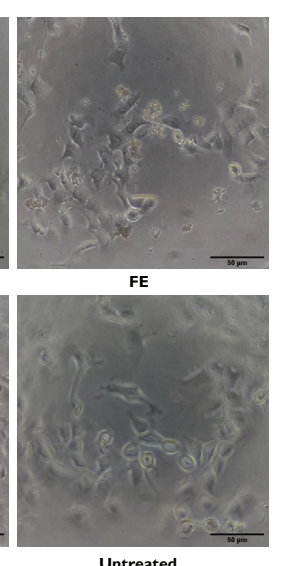

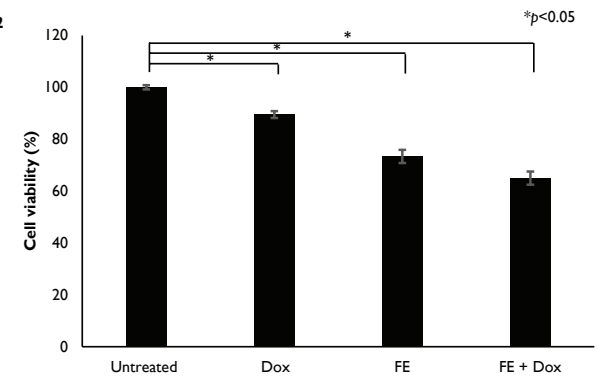

Figure 3. 4T1 cells viability after a combination treatment of FE and Dox. (1) 4T1 cell morphology after treatment with FE and in combination with Dox. Observation was performed using an inverted microscope with 100x magnification. (2) Graph of 4T1 cell viability after treatment with FE and combination with Dox. Significant differences between the two treatments were determined using One-Way ANOVA. 

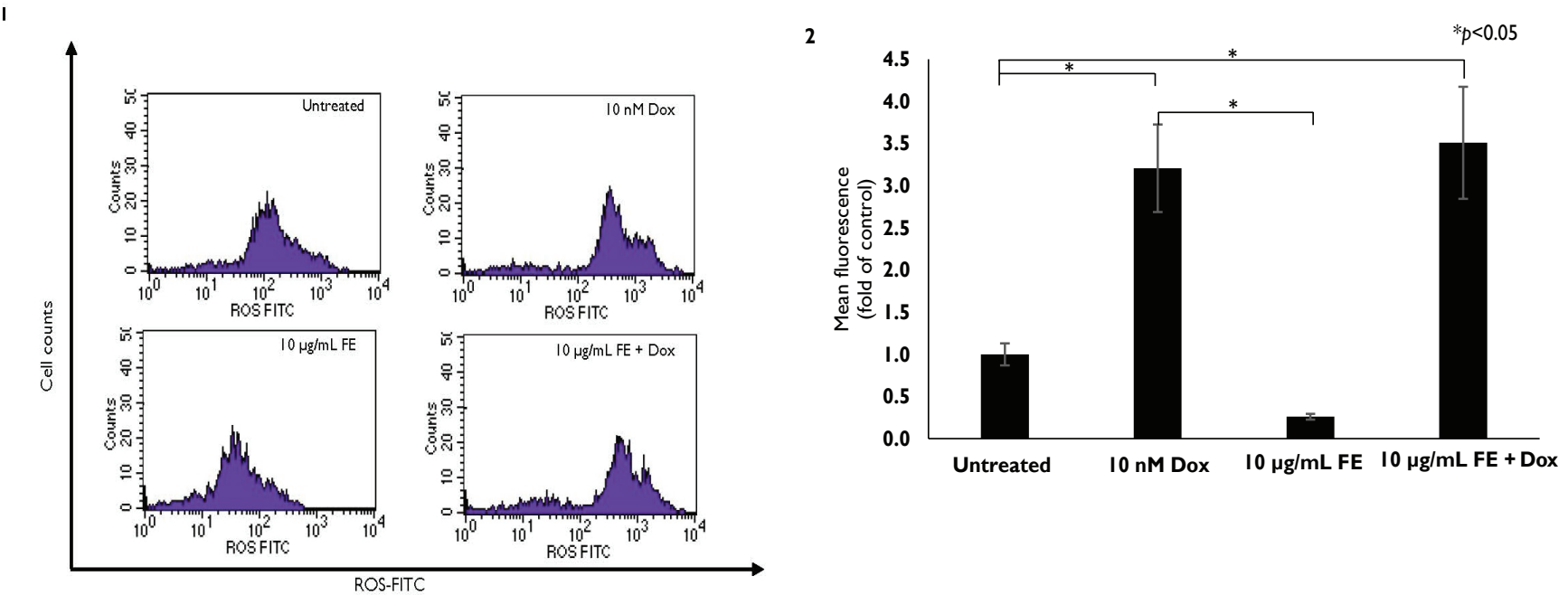

Figure 4. Effect of FE on intracellular ROS levels in 4T1 cells. (1) ROS-FITC profile vs Cell Counts 4T1 cells without treatment, after treatment of Dox, FE, and its combination. (2) ROS level profile of 4T1 cells on indicated treatments. The significance between treatments was determined using ANOVA One Way test.

\section{Effect of Fingerroot Extract on MMP-9 ex- pression in $4 \mathrm{~T} 1$ cells}

We observed MMP-9 expression to understand the initial of metastasis progression that facilitate cell migration. Our results showed that 24 $\mathrm{h}$ treatment of single FE and in combination with Dox significantly inhibited MMP-9 expression compared to Dox and untreated group (Figure 6). Thus, we suggest that both single and combination FE have anti-metastatic possessions by inhibiting MMP-9 expression.

\section{DISCUSSION}

Fingerroot and its constituent exhibit potency to be used as anti-cancer agent. The present study aimed to identify the potency of fingerroot as anti-proliferative and anti-migration agents against 4T1 metastasic breast cancer cell. We evaluated the evidence-based cytotoxic properties of the physiological changes caused by fingeroot. The results showed that fingerroot, in the form of ethanolic extract (FE), had $\mathrm{IC}_{50}$ value of $25.5 \pm 3.9 \mu \mathrm{g} /$ $\mathrm{mL}$ on $4 \mathrm{~T} 1$ cells. This finding indicated that $\mathrm{FE}$ had high cytotoxic potency towards $4 \mathrm{~T} 1$ cells according to Prayong, et al. (2008). FE was already known to exhibit high cytotoxic potential in various cells, such as MCF-7 breast cancer cells and HeLa cervical cancer cells (Zaeoung, et al., 2005; Listyawati, et al., 2016). Furthermore, flavonoid compound, in the form of isolates and synthesized from fingerroot, such as panduratin $\mathrm{A}$, boesenbergin $\mathrm{A}$, cardamonin, and pinostrobin, are also known to exhibit anticancer activity towards various cancer cell line (Cheah, et al., 2011; Isa, et al.; 2013, Jia, et al., 2016; Xian, et al., 2012). TLC analysis indicated the presence of flavonoid compounds and pinostrobin as fingerroot marker compound. FE used in this study represents the content of fingerroot active compounds, especially the flavonoid content. The content of these compounds supports the potential effects of FE as an anticancer agent.

High cytotoxic potency of extract, lead FE to be developed as a co-chemotherapy agent. Since we are now facing to chemotherapeutic drug problems, including Dox, a choice of drug in breast cancer therapy remains to have low-effectiveness, correlates with resistance and metastasis incidence, and toxic for healthy cells (Fimognari, et al., 2006). Therefore, natural co-chemotherapy agents will be 


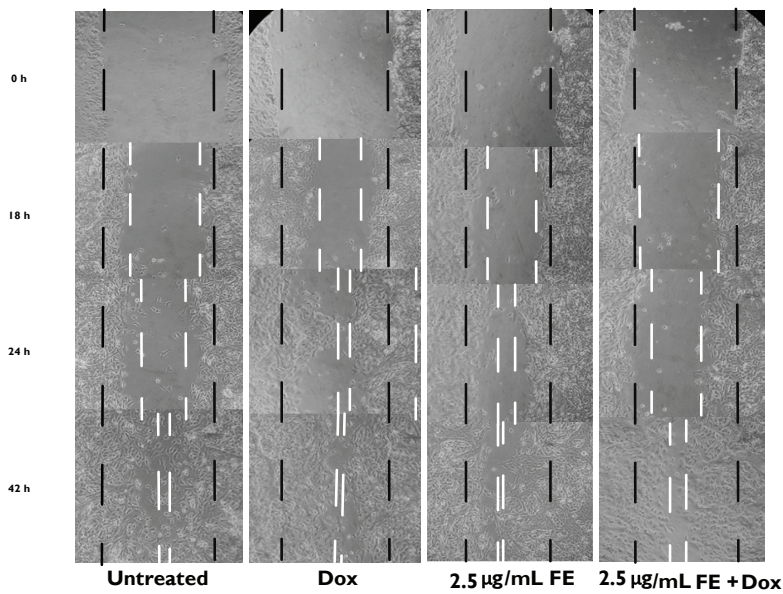

2

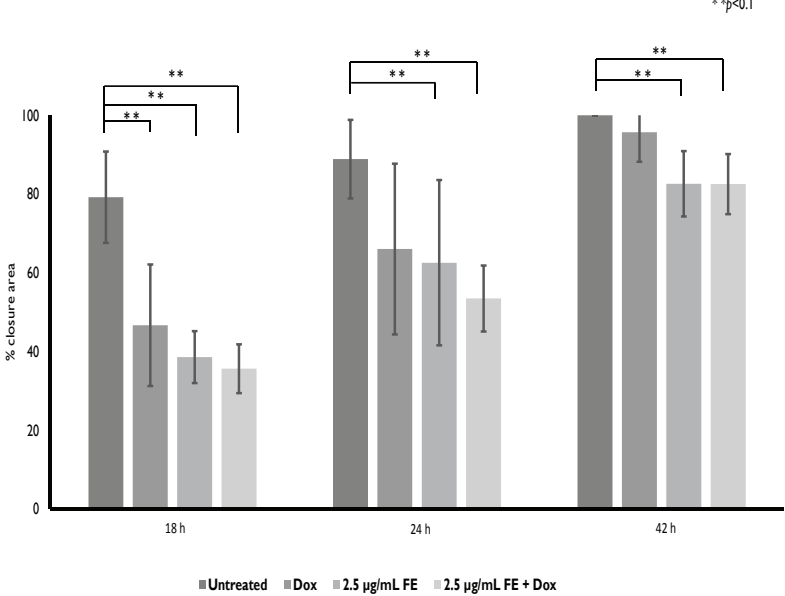

Figure 5. The effect of FE treatment on 4T1 cell migration. (1) Inhibitory activity of cell migration after treatment FE, Dox, and its combination. (2) The quantification of closure area percentage on each treatment at 18,24 , and $42 \mathrm{~h}$. Statistical analysis of $\%$ closure on each treatment at 18,24 , and $42 \mathrm{~h}\left({ }^{* *} p<0.1\right)$ by ANOVA one-way test compared to untreated cells.

useful to improve the efficacy and reduce side effects of synthetic commercial drugs (Bastl, et al., 2007). In a more in-depth study of changes in cell physiology due to the administration of extracts and in combination with Dox showed impressive results toward $4 \mathrm{~T} 1$ cells. Combination treatment of $10 \mu \mathrm{g} / \mathrm{mL}$ FE and $10 \mathrm{nM}$ Dox were carried out on 4T1 cells to understand its potency to develop FE as co-chemotherapeutic agent. We used Dox at concentration of $10 \mathrm{nM}$, which did not possess high anti-proliferative activity towards $4 \mathrm{~T} 1$ as shown by similar cell viability profile compared to untreated cell (Amalina, et al., 2017). The results showed that the combination of FE and Dox decreased the percentage of cell viability compared to a single Dox. So, it can be assumed that a single FE as well as its combination with Dox have inhibitory activity towards 4T1 cells. Further, FE can be developed as Dox co-chemoterapy agent.

One characteristic of cancer in general is its ability to do energy metabolism reprogramming which needed to support cell growth and proliferation (Hanahan and Weinberg, 2011). To meet the energy needs, cancer cells manipulate compounds in metabolic pathways such as ROS and an- tioxidant enzyme. Optimizing the use of ROS can be used by cancer cells to maintain their survival. Thus, we suggested that the cytotoxic effect of FE was probably related to the increased level of ROS. We then continued our study for possible pathways that affect cell growth inhibition through the measuring ROS level using DCFDA-staining assay.

ROS level measurements were carried out on 4T1 cells by using Dox as a positive control and to understand the effect of its combination with FE, since Dox is well known as ROS inducer, that boost ROS overproduction inside mitochondria (Asensio-López, et al., 2016). Interestingly, we found a different result that single FE at concentrations of $10 \mu \mathrm{g} / \mathrm{mL}$ reduced intracellular ROS levels, but its combination with $10 \mathrm{nM}$ Dox increased intracellular ROS levels. Cancer cells have the ability to modify or reprogram cell metabolism to support effective proliferation (Hanahan \& Weinberg, 2011). However, high levels of ROS can damage cells so that strict control is needed. Tumor initiation results in increased metabolic activity and ROS production, thereby triggering tumorigenesis. However, in the process of tumors, some cells encounter hypoxic nutrient-deprived microenvi- 


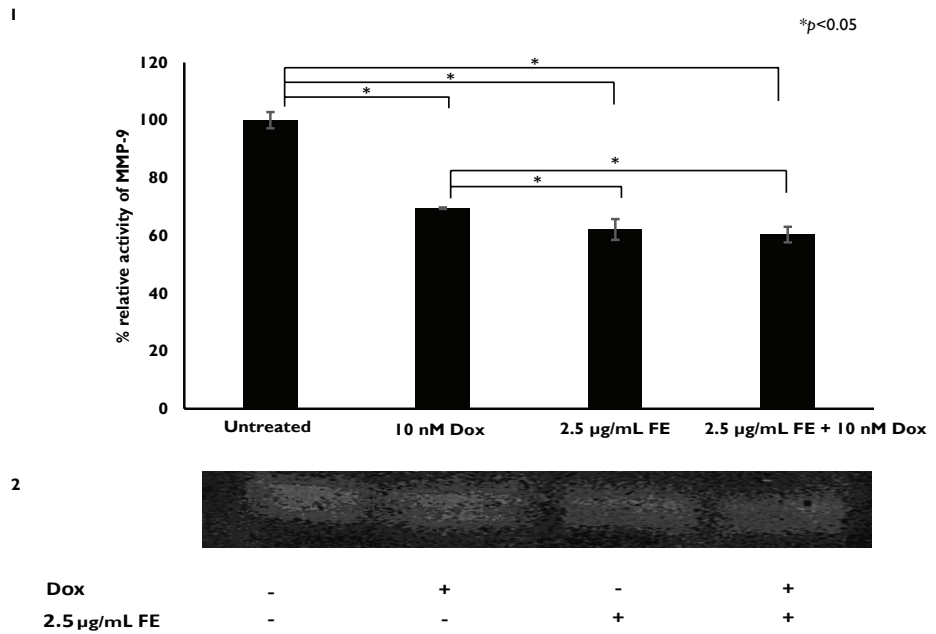

Figure 6. The effect of FE treatment on MMP-9 expression in 4T1 cells. (1) The quantification of band intensity of MMP-9 expression after treatment with FE and its combination with $10 \mathrm{nM}$ Dox. (2) Band profile of MMP-9 expression. Band intensities were quantified using Image $(n=3)$. The percent band intensity was analyzed using One-Way ANOVA $\left({ }^{*} p<0.05\right)$.

ronments. To prevent the accumulation of ROS to toxic levels, cancer cells increase antioxidant capacity to maintain ROS in non-lethal levels (Vyas, et al., 2016). The reduction of ROS level in single FE treatment is suspected due to an increase of antioxidant enzymes as a mechanism for eradicating free radicals (Abe and Berk, 1998; Murdoch, et al., 2006; Nabeebaccus, et al., 2011). ROS eradication is facilitated by non-enzymatic molecules (i.e. glutathione, flavenoids and vitamins $\mathrm{A}, \mathrm{C}$ and $\mathrm{E}$ ) or through antioxidant enzymes which specifically scavenge different kinds of ROS (Liou and Storz, 2010).

Whilst, the increasing of ROS level in the combination of FE and Dox is caused by Dox ability to induce ROS level. Excessive increase in intracellular ROS levels as mediated by chemotherapeutics, can induce cell cycle arrest, senescence or cell death of tumor cells (Liou and Storz, 2010). An increase of ROS level in cancer cells is expected to exceed the toxic limit so that the cell is able to undergo apoptosis (Panieri and Santoro, 2016). The rate of cell death is inversely proportional to the level of cellular ROS when therapeutic agents reach its toxic levels (Zhu, et al., 2014).
Previous research show that Boesenbergin A and pinostrobin in $\mathrm{FE}$, found to be able to induce cell death through formation of ROS (Xian, et al., 2012; Isa, et al., 2013). Further observations regarding FE cytotoxic activity against 4T1 highly metastasis cancer cells were carried out through migration with scratch wound healing assay and MMP-9 expression with gelatin zymography.

Since we used 4T1 breast cancer cells which characterized as highly metastatic (Pulaski and Ostrand-Rosenberg, 1998), we continued our study on cell migration assay. We used $\mathrm{FE}$ at concentrations of $2.5 \mu \mathrm{g} / \mathrm{mL}$ to minimize the cytotoxic effect of FE on $4 \mathrm{~T} 1$ cells, so the gap closure is purely caused by the anti-migratory effect of FE, not its anti-proliferation activity. Dox was used as a positive control, wherever known to induce cell migration through lamellipodia formation at a concentration of $10 \mathrm{nM}$ (Amalina, et al., 2017). Dox also known to activates the RhoA/MLC pathway and enhances breast cancer cell migration and invasion (Liu, et al., 2019).

The combination of FE and Dox treatment showed the highest inhibition of migration with \% closure of 35.7 compared to the single Dox and FE 
with \% closure of 46.7 and 38.6, respectively (18 h). However, the $\%$ closure of a single FE treatment and its combination with Dox did not differ significantly from that of a single Dox treatment. Whereas after $42 \mathrm{~h}$, the \% closure of Dox single treatment was higher than the single FE treatment and its combination with Dox but not statistically different. Anti-migratory activity of FE was indicated before, in which, Panduratin A, an active compound in fingerroot, was reported to be able to inhibit phosphorylation of the mitogen activated protein kinase (MAPK) family, namely ERK, JNK and p38 (Shim, et al., 2008) which are regulators of cell migration (Huang, et al., 2004). Pinocemberin which is also present in fingerroot is known to be able to inhibit migration of Y-79 retinoblastoma cells through suppression of EMT induced by TGF- $\beta 1$ through the $\mathrm{p} 38 \alpha$ pathway (Chen, et al., 2014). Further, FE and in combination with Dox inhibited cells migration after $48 \mathrm{~h}$ observation in MCF-7/ HER2 breast cancer cells (Fadliyah, et al., 2018). Thus, FE is also believed to inhibit migration in 4T1 breast cancer cells.

The process of invading cancer cells involves proteins to degrade extracellular matrix components, one of which is matrix metalloproteinases (MMPs) (Gialeli, et al., 2010). Consequently, it is also important to know the potency of FE in inhibiting cell invasion by observation of MMP-9 expression, that play a role in the stages of migration and metastasis. Dox inhibited MMP9 protein expression up to $30.5 \%$ compared to untreated cells. Whereas, the single FE treatment and its combination with Dox were significantly able to reduce the percentage of band intensity compared to untreated and single Dox at 37.9 and 39.7\%, respectively. Previous research revealed that FE was able to suppress the expression of MMP-9 on KB (human oral epidermoid cell line) cells induced by Porphyromonas gingivalis supernatant through decreased regulation of MAPK phosphorylation, as well as through inhibition of AP-1 and nuclear factor (NF)- $\mathrm{B}$ (Gwon and Hwang, et al., 2009).
Further, FE caused lower expression of MMP-9 in MCF-7/HER2 (Fadliyah, et al., 2018). Thus, it is possible that anti-proliferative and anti-migratory effect of FE correlates with the inhibition of MMP9 expression. In the present study, we found that FE cytotoxic properties are more potent than the anti-migration properties, it will be better to do further investigation on its cytotoxic pathways, such as anti-proliferative assay, cell cycle assay, and apoptotic assay.

\section{CONCLUSION}

Fingerroot (Boesenbergia pandurata) Extract (FE) has anti-proliferative and anti-metastatic potential, so that FE could be developed as a chemo preventive agent for metastatic breast cancer.

\section{ACKNOWLEDGMENT}

The authors thank Ms. Febri Wulandari for her correction and discussion.

\section{REFERENCES}

Abe, J. and Berk, B.C., 1998, Reactive oxygen species as mediators of signal transduction in cardiovascular disease, Trends Cardiovasc Med, 8, 59-64.

Adrada, B.E., Miranda, R.N., Rauch, G.M., Arribas, E., Kanagal-Shamanna, R., Clemens, M.W., et al., 2014, Breast implant-associated anaplastic large cell lymphoma: sensitivity, specificity, and findings of imaging studies in 44 patients, Breast cancer research and treatment, 147(1), 1-14.

Amalina, N.D., Nurhayati, I.P. and Meiyanto, E., 2017, Doxorubicin Induces Lamellipodia Formation and Cell Migration, Indones. J. Cancer Chemoprevent, 8(2), 61-67.

Asensio-López, M.C., Soler, F., Sánchez-Más, J., Pascual-Figal, D., Fernández-Belda, F. and Lax, A., 2016, Early oxidative damage induced by doxorubicin: source of production, protection by GKT137831 and effect on Ca2+ transporters in 
HL-1 cardiomyocytes, Arch Biochem Biophys., 594, 26-36.

Bandyopadhyay, A., Long W., Joseph A., Yuping T., Shu L., I-Tien, Y., et al., 2010, Doxorubicin in Combination with a Small TGFb Inhibitor: A Potential NovelTherapy for Metastatic Breast Cancer in Mouse Models, PlosOne, 5(4), e10365.

Bao, L., Haque, A., Jackson, K., Hazari, S., Moroz, K. and Jetly, R., 2011, Increased Expression of P-Glycoprotein Is Associated with Doxorubicin Chemoresistance in the Metastatic 4T1 Breast Cancer Model, The American Journal of Pathology, 178, 838-852.

Bastl, A., Kaseirov, H., Den Hartog, G.J.M., Haenen, G.R.M.M., and Van Der Vijgh, W.J.F., 2007, Protectors Against Doxorubicin-Induced Cardiotoxicity: Flavonoids, Cell Biol Toxicol, 23, 39-47.

Blows, F.M., Driver, K.E., Schmidt, M.K., Broeks, A., Van Leeuwen, F.E., Wesseling, J., et al., 2010, Subtyping of breast cancer by immunohistochemistry to investigate a relationship between subtype and short and long term survival: a collaborative analysis of data for 10,159 cases from 12 studies, PLoS Med, 7(5), e1000279.

Brooks, S.A., Lomax-Browne, H.J., Carter, T.M., and Kinch, C.E., 2010, Molecular interaction in cancer cell metastasis, Acta Hiatochemica, 112, 3-25.

Chahyadi, A., Hartati, R., Wirasutisna, K.R. and Elfahmi, 2014, Boesenbergia pandurata Roxb., An Indonesian Medicinal Plant: Phytochemistry, Biological Activity, Plant Biotechnology, Procedia Chem, 13, 13-37.

Cheah, S.C., Appleton, D.R., Lee, S.T., Lam, M.L., Hadi, A.H. and Mustafa, M.R., 2011, Panduratin A inhibits the growth of $A 549$ cells through induction of apoptosis and inhibition of NF-kappaB translocation, Molecules, 16, 2583-2598.

Chen, K.S., Ming, D.S., Chi, S.C., and Yuan, W.S., 2014, Pinocembrin suppresses TGF-B1-induced epithelialmesenchymal transition and metastasis of human Y-79 retinoblastoma cells through inactivating avB3 integrin/FAK/p38a signaling pathway, Cell \& Bioscience, 4, 14.

Fadliyah, H., Putri, N.B., Walidah, Z., Nurhayati, I.P., Ikawati, M. and Meiyanto, M., 2018, Anti-metastatic Profiles of Boesenbergia pandurate towards MCF-7/HER2 Cells, Indones. J. Cancer Chemoprevent., 9(2), 68-77.

Fimognari, C., Nusse, M. N., Lenzi, M., Sciuscio, D., Cantelli-Forti, G. and Hrelia, P., 2006, Sulforaphane Increases the Efficacy of Doxorubicin in Mouse Fibroblasts Characterized by p53 Mutations, Mutation Research, 601, 92-101.

Gialeli, C., Theocharis, A.D. and Karamanos, N.K., 2011, Roles of matrix metalloproteinases in cancer progression and their pharmacological targeting, FEBS Journal, 278, 16-27.

Gwon, S.H. and Hwang, J.K., 2009, Kaempferia pandurata Roxb. inhibits Porphyromonas gingivalis supernatant-induced matrix metalloproteinase- 9 expression via signal transduction in human oral epidermoid cells, Journal of ethnopharmacology, 123(2), 315-324.

Hanahan, D., and Weinberg, R.A., 2011, Hallmarks of cancer: the next generation, Cell, 144 (5), 646-74.

Health Ministry of Indonesia, 2008, Farmakope Herbal Indonesia, $1^{\text {st }}$ Edition, Health Ministry of Indonesia, Jakarta.

Huang, C., Jacobson, K. and Schaller, M.D., 2004, MAP kinases and cell migration, Journal of cell science, 117(20), 4619-4628.

Isa, N.M., Abdul, A.B., Abdelwahab, S.I., Abdullah, R., Sukari, M.A., Kamalidehghan, B., et al., 2013, Boesenbergin A, a chalcone from Boesenbergia rotunda induces apoptosis via mitochondrial dysregulation and cytochrome $c$ release in A549 cells in vitro: Involvement of HSP70 and Bcl2/Bax signalling pathways, J Funct Foods, 5, 87-97.

Jia, D., Tan, Y., Liu, H., Ooi, S., Li, L., Wright, K., et al., 2016, Cardamonin reduces chemotherapy-enriched breast cancer stem-like cells in vitro and in vivo, Oncotarget, 7(1), 771-785. 
Kaur, P., Nagaraja, G.M., Zheng, H., Gizachew, D., Galukande, M., Krishnan, S., et al., 2012, A mouse model for triple-negative breast cancer tumor-initiating cells (TNBC-TICS) exhibits similar aggressive phenotype to the human disease, BMC Cancer, 12, 120.

Kirana, C., Jones, G.P., Record, I.R., and Mclontosh, G.W., 2007, Anticancer properties of panduratin A isolated from Boesenbergia pandurata (Zingiberaceae), J Nat Med, 61, 131-137.

Lai, S.L., Cheah, S.C., Wong, P.F., Noor, S.M., and Mustafa, M.R., 2012, In Vitro and In Vivo Anti-Angiogenic Activities of Panduratin A, PLoS ONE, 7(5), e38103.

Liang, C., Park, A.Y., and Guan, J., 2007, In vitro scratch assay: a convenient and inexpensive method for analysis of cell migration in vitro, Nature Protocols, 2(2), 329-333.

Liotta, L.A., Steeg, P.S., and Stetler-Stevenson, W.G., 1991, Cancer metastasis and angiogenesis: an imbalance of possitive and negative regulation, Cell, 64, 327-336.

Liou, G.Y., and Storz, P., 2010, Reactive oxygen species in cancer, Free Radic Res., 44(5).

Listyawati, S., Sismindari, Mubarika, S., Murti, Y.B., and Ikawati, M. , 2016, Anti-Proliferative Activity and Apoptosis Induction by an Ethanolic Extract of Boesenbergia pandurata (Roxb.) Schlecht, Asian Pac J Cancer Prev, 17(1), 183-187.

Liu, C.L., Chen, M.J., Lin, J.C., Lin, C.H., Huang, W.C., Cheng, S.P., et al., 2019, Doxorubicin Promotes Migration and Invasion of Breast Cancer Cells through the Upregulation of the RhoA/MLC Pathway, J Breast Cancer, 22(2), 185-195.

Ma, K.K., Chau, W.W., Wong, C.H.N., Wong, K., Fung, N., Lee, A.J.T., et al., 2012, Triple Negative Status Is A Poor Prognostic Indicator In Chinese Women With Breast Cancer: A Ten Tear Review, Asian Pac J Cancer Prev., 13(5), 2109-2114.

Mehta, R.R., Katta, H., Kalra, A., Patel, R., Gupta, A., Alimirah, F., et al., 2013, Efficacy and mechanism of action of Deguelin in suppressing metastasis of $4 \mathrm{~T} 1$ cells, Clinical \& experimental metastasis, 30(7), 855-866.

Mosmann, T., 1983, Rapid colorimetric assay for cellular growth and survival: application to proliferation and cytotoxicity assays, Journal of Immunological Methods, 65, 55-63.

Murdoch, C.E., Grieve, D.J., Cave, A.C., Looi, Y.H., and Shah, A.M., 2006, NADPH oxidase and heart failure, Curr Opin Pharmacol, 6, 148-153.

Nabeebaccus, A., Zhang, M. and Shah, A.M., 2011, NADPH oxidases and cardiac remodelling, Heart Fail Rev, 16, 5-12.

Nurrachma, M.Y., Fadliyah, H. and Meiyanto, E., 2018, Fingerroot (Boesenbergia pandurata): A Prospective Anticancer Therapy, Indones. J. Cancer Chemoprevent., 9(2), 102-109.

Panieri, E. and Santoro, M.M., 2016, ROS homeostasis and metabolism: a dangerous liason in cancer cells, Cell Death Dis, 7, e2253.

Prayong, P., Barusrux, S. and Weerapreeyakul, N., 2008, Cytotoxic activity screening of some indigenous Thai plants, Fitoterapia, 79(7-8), 598601.

Pulaski, B.A. and Ostrand-Rosenberg, S., 1998, Reduction of established spontaneous mammary carcinoma metastases following immunotherapy with major histocompatibility complex class II and B7.1 cell-based tumor vaccines, Cancer Res, 58(7), 1486-1493.

Shim, J.S., Kwon, Y.Y., Han, Y.S. and Hwang, J.K., 2008, Inhibitory effect of panduratin A on UV-induced activation of mitogen-activated protein kinases (MAPKs) in dermal fibroblast cells, Planta medica, 74(12), 1446-1450.

Sohn, J.H., Han, K.L., Lee, S.H. and Hwang, J.K., 2005, Protective Effects of Panduratin Against Oxidative Damage of tert-Butylhydroperoxide in Human HepG2 Cells, Biological and Pharmaceutical Bulletin, 28(6), 1083-1086.

Tewtrakul, S., Subhadhirasakul, S., Puripattanavong, J. and Panphadung, T., 2003, HIV-1 protease inhibitory substances from the rhizomes of Boesenbergia pandurata Holtt., Songklanakarin J Sci Technol, 25(4), 504-508. 
Vinod, B.S., Antony, J., Nair, H.H., Puliyappadamba, V.T, Saikia, M., Narayanan, S.S., Bevin, A. and Anto, R.J., 2013, Mechanistic evaluation of the signaling events regulating curcumin-mediated chemosensitization of breast cancer cells to 5-fluorouracil, Cell Death and Disease, 4(2), e505.

Vyas, S., Zaganjor, E. and Haigis, M.C., 2016, Mitochondria and cancer, Cell, 166, 555-566.

Wagner, H. and Bladt, S., 1996, Plant Drug Analysis: A Thin Chromatography Atlas, Springer Science \& Bussiness Media, Berlin.

Wilson, T.R., Johnston, P.G. and Longley, D.B., 2009, Anti-apoptotic mechanisms of drug resistance in cancer, Curr Cancer Drug Targets, 9, 307-319. Xian, Y.F., Ip, S.P., Lin, Z.X., Mao, Q.Q., Su, Z.R., and Lai, X.P., 2012, Protective effects of pinostrobin on B-amyloid-induced neurotoxicity in $\mathrm{PC} 12$ cells, Cell Mol Neurobiol, 32(8), 1223-1230.

Zaeoung, S., Plubrukarn, A. and Keawpradub, N., 2005, Cytotoxic and free radical scavenging activities of Zingiberaceous rhizomes, Songklanakarin J Sci Technol, 27(4), 799-812.

Zhu, C.P., Hu, W., Wu, H. and Hu, X., 2014, No evident dose-response relationship between cellular ROS level and its cytotoxicity - a paradoxical issue in ROS-based cancer therapy, Sci Rep, 4, 5029. 